\title{
THE RELATIONSHIP BETWEEN CASH GAP AND PROFITABILTY: AN EMPRICAL STUDY FROM TURKEY
}

\author{
DOI: 10.17261/Pressacademia.2018.861 \\ PAP- V.7-2018(14)-p.93-96
}

\section{Bengu Vuran ${ }^{1}$, Burcu Adiloglu²}

${ }^{1}$ Istanbul University, Avcilar Campus, Faculty of Business Administration, Finance Department, Istanbul, Turkey. benguv@istanbul.edu.tr, ORCID: 0000-0002-2428-1543

${ }^{2}$ Istanbul University, Avcilar Campus, Faculty of Business Administration, Accounting Department, Istanbul, Turkey. adiloglu@istanbul.edu.tr, ORCID: 0000-0001-9680-1408

To cite this document

Vuran, B., Adiloglu, B. (2018). The relationship between cash gap and profitability: an emprical study from Turkey. PressAcademia Procedia (PAP), V.7, p.93-96

Permemant link to this document: http://doi.org/10.17261/Pressacademia.2018.861

Copyright: Published by PressAcademia and limited licenced re-use rights only.

\begin{abstract}
Purpose- Cash gap or cash conversion cycle refers to the time interval between the date when a company pays cash out for the inventory it purchases and the date it receives cash from customers for the same inventory. That interval must be financed. Management of cash conversion cycle is vital issue in corporate financial management since it directly affects the profitability of the firms. The purpose of this study is to analyze the relationship of cash gap and corporate profitability.

Methodology- The data set includes all manufacturing and merchandising firms listed in Borsa Istanbul (BIST) for the year 2017. The financial sector firms are excluded since their financial statements have different aspects. Regression and correlation analyses are conducted to examine the relationship between the cash gap and profitability.

Findings- The results of the study evaluates how cash conversion cycle affects the profitability and show if there is a statistical significance between profitability the cash conversion cycle.

Conclusion- Managers of the companies that handle the cash conversion cycle correctly and keep each different component (accounts receivables, accounts payables, inventory) to an optimum level can create profits and seems successful from the views of investors. The study also contributes to the literature on the issue of relationship between cash gap and the firm's profitability.
\end{abstract}

Keywords: Cash gap, working capital management, profitability, Borsa Istanbul, cash cycle.

JEL Codes: G30, G32, M41

\section{INTRODUCTION}

Cash gap or cash conversion cycle refers to the time interval between the date when a company pays cash out for the inventory it purchases and the date it receives cash from customers for the same inventory. That interval must be financed. Management of cash conversion cycle is vital issue in corporate financial management since it directly affects the profitability of the firms. The longer the time lag, the larger the investment in working capital. However, corporate profitability might decrease with the cash conversion cycle, if the costs of higher investment in working capital rise faster than the benefits of holding more inventories and /or granting more trade credit to customers.

The purpose of this study is to analyze the relationship of cash gap and corporate profitability of Turkish manufacturing companies operating in Borsa Istanbul for the year 2017.

The rest of the paper is organized as follows: Section 2 provides a detailed survey of past studies. Section 3 explains the data (variables employed) and methodology while the findings are presented in Section 4. Finally, Section 5 gives the conclusion.

\section{LITARATURE REVIEW}

Lazaridis and Tryfonidis (2006) conducted a cross sectional analysis by using 131 firms listed on Athens Stock Exchange for the period 20012004. They found statistically significant relationship between profitability measured through gross profit margin and cash conversion cycle and its components (accounts receivables, accounts payable, inventory).

Garcia and Martinez (2007) tested the effect of working capital management on SME profitability using panel data methodology by 8,872 observations covering the period 1996-2002. The results demonstrated that managers could create value by reducing inventory level and shortening the cash conversion cycle improves the firm's profitabilty. 
Mathuva (2009) examined the influence of working capital management components on corporate profitability by using 30 listed firms on Nairobi Stock Exchange for the periods 1993-2008 using pooled ordinary least square (OLS) and the fixed effect regression models. He found that there is a highly significant negative relationship between average collection period and profitability, and there is a highly significant positive relationship between the days in inventory, average payment period and profitability.

Gill, Biger and Mathur (2010) examined 88 American firms listed on NYSE for the period for 2005-2007. They found statistically significant relationship between the cash conversion cycle and profitability measured through gross profit margin.

Napompech (2012) studied the effects of working capital management on profitability using regression analysis based on a panel sample of 255 companies listed on Stock Exchange of Thailand from 2007 through 2009. The results revealed a negative relationship between the gross operating profits and inventory conversion period and the receivables collection period.

Zakari and Saidu (2016) empirically tested the effect of cash conversion cycle on corporate profitability (ROA) of the firms listed on Nigerian Stock Exchange using multiple regression analysis for the period from 2010 to 2014 . The findings indicate significant positive relationship between cash conversion cycle and corporate profitability.

\section{DATA AND METHODOLOGY}

This study aims to investigate the relationship between the length of cash conversion cycle and corporate profitability of Turkish manufacturing companies. The data used in this study is obtained from financial statements of corporations which are taken from www.kap.gov.tr website. The sample is comprised of 168 manufacturing companies listed in Borsa Istanbul. Multiple regression analysis is conducted for the year 2017. Table 1 exhibits the definition of the data.

\section{Table 1: Data Set}

\begin{tabular}{|l|l|l|}
\hline & Variable Name & Calculation \\
\hline $\begin{array}{l}\text { Dependent } \\
\text { Variable }\end{array}$ & Return on Asset (ROA) & EBIT / Total Assets \\
\hline \multirow{4}{*}{$\begin{array}{l}\text { Independent } \\
\text { Variables }\end{array}$} & Cash Conversion Cycle ( CCC) & Average Collection Period + Days in Inventory - Average Payment Period \\
\cline { 2 - 3 } & Current Ratio & Current Assets / Current Liabilities \\
\cline { 2 - 3 } & Debt Ratio & Total Debt / Total Assets \\
\cline { 2 - 3 } & Growth in Total Assets & (Total Assets $\mathrm{t}+1$ / Total Assets $\mathrm{t}$ ) -1 \\
\hline
\end{tabular}

Growth in total assets is used as the proxy for firm growth. Current ratio, debt ratio, firm growth are used as control variables. The descriptive statistics for the sample are reported in Table 2. All variables are calculated using financial statement values. Hence, they are relied on "book values" as of the date of the financial reports.

\section{Table 2: Descriptive Statistics of the Variables}

\begin{tabular}{|l|l|l|l|l|l|}
\hline & N & Minimum & Maximum & Mean & Standart Deviation \\
\hline Return on Asset (ROA ) & 168 & $-0,11$ & 0,37 & 0,0873 & 0,0788 \\
\hline Cash Conversion Cycle (CCC) & 168 & 0,25 & 8,02 & 1,7051 & 1,1782 \\
\hline Current Ratio & 168 & 0,00 & 2,21 & 0,2723 & 0,2350 \\
\hline Debt Ratio & 168 & $-0,18$ & 1,30 & 0,2062 & 0,1922 \\
\hline Growth in Total Assets & 168 & $-89,00$ & 462,85 & 113,23 & 95,9899 \\
\hline
\end{tabular}

Table 3 provides Pearson Correlation for the variables. It is intrinsically used to see the sign of multicolliniarity between the independent variables. Although another test is used to detect multicolliniarity more seriously, in the first instance, pearson correlation can also give an idea for the existence of multicolliniarity.

Table 3: Pearson Correlation Statistics

\begin{tabular}{|l|l|l|l|l|l|}
\hline ROA & & ROA & Current Ratio & Debt Ratio & gtotal_assets \\
\hline & Pearson Correlation & $\mathbf{1}$ & $0,265^{* *}$ & 0,048 & $0,202^{* *}$ \\
\hline & Sig. (2-tailed) & & 0,000 & 0,538 & 0,008 \\
\hline & $\mathbf{N}$ & 168 & 168 & 168 & 168 \\
\hline $\begin{array}{l}\text { Current } \\
\text { Ratio }\end{array}$ & Pearson Correlation & $0,265^{* *}$ & $\mathbf{1}$ & $-0,482^{* *}$ & $-0,072$ \\
\hline & Sig. (2-tailed) & 0,000 & & 0,000 & 0,353 \\
\hline & $\mathbf{N}$ & 168 & 168 & 168 & 168 \\
\hline Debt Ratio & Pearson Correlation & 0,048 & $-0,482^{* *}$ & $\mathbf{1}$ & 0,027 \\
\hline & Sig. (2-tailed) & 0,538 & 0,000 & & 0,724 \\
\hline & $\mathbf{N}$ & 168 & 168 & 168 & 168 \\
\hline gtotal assets & Pearson Correlation & $0,202^{* *}$ & $-0,072$ & 0,027 & $\mathbf{1}$ \\
\hline & Sig. (2-tailed) & 0,08 & 0,353 & 0,724 & 168 \\
\hline
\end{tabular}

\footnotetext{
** Correlation is significant at the 0,001 level (2-tailed).
} 
It is important to examine the correlation coefficient between independent variables. As it is shown in Table 3 , there is $48,2 \%$ correlation between current ratio and debt ratio and it is significant at $1 \%$. There seems to be multicollinearity but the existence of multicollinearity is examined by using VIF statistics in further section. The correlation matrix table reveals also positive and moderate correlation between ROA, since it is dependent variable this correlation is not meaningful.

\section{FINDINGS}

In order to investigate the effect of cash conversion cycle on the corporate profitability multiple regression analysis has been performed for 168 companies for the year 2017. The regression analysis finds out the effect and the relationship of explanatory variables with profitability of companies. In this study ROA is the dependent variables and regression model is conducted for these variables separately.

Table 4 displays the results of model summary.

Table 4: Model Summary: Dependent Variable ROA

\begin{tabular}{|l|l|l|l|l|l|}
\hline Model & $\mathbf{R}$ & R Square & Adjusted R Square & Std. Error of Estimate & Durbin-Watson \\
\hline 1 & 0,419 & 0,175 & 0,155 & 0,07241 & 2,030 \\
\hline
\end{tabular}

Durbin Watson test is a measure of autocorrelation in residuals of regression analysis. As it is seen in Table 4,since the Durban Watson test statistic is 2 , there is no autocorrelation in residuals. The R-Square, coefficient of determination, indicates how well the model fits the data. It indicates the proportion of variance in the dependent variable that is explained by the independent variables. In this model, it is seen that $17.5 \%$ of change in ROA is explained by the independent variables in the model.

The second step of the regression analysis is ANOVA table. The significance $F$ is the probability that the null hypothesis in the regression model cannot be rejected. In other words, it indicates the probability that all the coefficients in our regression output are actually zero. Table 5 shows the ANOVA results.

Table 5: ANOVA Results

\begin{tabular}{|l|l|l|l|l|l|}
\hline Model & Sum of Squares & df & Mean Square & F & Sig. \\
\hline $\mathbf{1}$ Regression & 0,183 & 4 & 0,046 & 8,725 & 0,000 \\
\hline Residual & 0,860 & 164 & 0,05 & & \\
\hline Total & 1,043 & 168 & & & \\
\hline
\end{tabular}

ANOVA results reveal that significance of $F$ statistic is lower than $5 \%$ which indicates that the model is meaningful.

To understand which independent variables should be added in the regression model, it is better to analyze the next table.

Table 6: Coefficients of the Model

\begin{tabular}{|l|l|l|l|l|l|l|l|}
\hline Model & \multicolumn{2}{|l|}{ Unstandardized Coefficients } & $\begin{array}{l}\text { Standardized } \\
\text { Coefficients }\end{array}$ & & \multicolumn{2}{l|}{ Collinearity Statistics } \\
\hline & B & Std. Error & Beta & t & Sig. & Tolerance & VIF \\
\hline Constant & 0,014 & 0,018 & & 0,754 & 0,452 & & \\
\hline Current Ratio & 0,028 & 0,006 & 0,420 & 5,084 & 0,000 & 0,735 & 1,360 \\
\hline Debt Ratio & $-0,073$ & 0,027 & $-0,217$ & $-2,672$ & 0,008 & 0,760 & 1,316 \\
\hline gtotal_assets & 0,087 & 0,029 & 0,211 & 2,954 & 0,004 & 0,984 & 1,017 \\
\hline CCC & 0,000 & 0,000 & $-0,128$ & $-1,721$ & 0,087 & 0,906 & 1,104 \\
\hline
\end{tabular}

The variance inflation factor (VIF) identifies correlation between independent variables and the strength of that correlation.

A value of 1 indicates that there is no correlation between this independent variable and any others. It can be concluded that there is no multicollinearity between the independent variables.

Table 6 also gives the resut of the model to form the regression equation. The regression model can be written as follows:

\section{$R O A=0,014+0,028$ Current Ratio - 0,073 Debt Ratio + 0,087 gtotal_assets}

As it is seen in the table; cash conversion cycle is not a significant variable on the profitability of manufacturing companies as measured by return on asset.

\section{CONCLUSION}

Regression analysis generates an equation to describe the statistical relationship between one or more predictor variables and the response variable. Regression analysis is used to produce an equation that will predict a dependent variable using one or more independent variables. It is found in this study that; there is a positive significant relationship between ROA and current ratio, debt ratio and growth rate in total assets for $5 \%$ significance and positive relationship with cash conversion cyle for $10 \%$ significance level. But the coefficient of CCC is near to zero. A possible further research can be done on companies for larger period by comparing Turkish companies with the companies from other countries. 


\section{REFERENCES}

Lazaridis, I., Tryfonidis, D. (2006). Relationship between working capital management and profitability of listed companies in the Athens stock exchange. http://ssrn.com/abstract=931591

Garcia-T., P.J., Martinez-Solano, P. (2007). Effects of working capital management on SME profitability. International Journal of Managerial Finance, Vol. 3 No. 2, pp. 164-177.

Gill, A., Biger, N., Mathur, N. (2010). The relationship between working capital management and profitability: evidence from the United States. Business and economics journal, 10(1), 1-9.

Mathuva, D. (2009). The influence of working capital management components on corporate profitability: a survey on Kenyan listed firms. Research Journal of Business Management, Vol 3: pp:1-11.

Napompech, K. (2012). Effects of working capital management on the profitability of Thai listed firms. International Journal of Trade, Economics and Finance, 3(3), 227.

Zakari, M., Saidu, S. (2016). The impact of cash conversion cycle on firm profitability: evidence from Nigerian listed telecommunication companies. Journal of Finance and Accounting, 4(6), 342. 